\title{
ReSEARChArticle
}

\section{Evaluation of nutritional quality, physical characteristics and functional properties of organically produced variety of red rice (Oryza sativa)}

\author{
Priyanka Joshi and Arti Sankhala
}

\begin{abstract}
SUMMARY
The present study is an investigation to evaluate nutritional quality, physical characteristics and functional properties of organically produced variety of red rice (Oryza sativa). Results revealed that red rice contained $9.6 \mathrm{~g}$ crude protein, 1.7 $\mathrm{g}$ crude fat, $1.5 \mathrm{~g}$ total ash, $2.3 \mathrm{~g}$ crude fibre, $73.3 \mathrm{~g}$ carbohydrates, $347 \mathrm{kcal}$ energy, $182 \mathrm{mg}$ calcium, $1.76 \mathrm{mg}$ iron and 1.52 $\mathrm{mg}$ zinc, respectively. Protein digestibility in-vitro of red rice was found to be $65.4 \%$ whereas iron bioavailability was observed to be $0.27 \mathrm{mg} / 100 \mathrm{~g}$ that pertaining to $15 \%$ availability of iron in the body. Anti-nutritional factors i.e. tannin and phytate content of red rice was found to be $0.29 \%$ and $0.96 \%$, respectively. Red rice had a strong antioxidant property (75\%). Results of physical characteristics and functional properties also showed that good water, oil absorption, emulsifying capacity. Organically produced variety of red rice were found to contain all essential nutrients and thus, can be recommended for regular use in daily diet to contribute various nutrients.
\end{abstract}

Key Words : Red rice, Nutritional composition, Antioxidant property, Functional property

How to cite this article : Joshi, Priyanka and Sankhala, Arti (2021). Evaluation of nutritional quality, physical characteristics and functional properties of organically produced variety of red rice (Oryza sativa). Internat. J. Plant Sci., 16 (2): 140-146, DOI: 10.15740/ HAS/IJPS/16.2/140-146, Copyright@ 2021: Hind Agri-Horticultural Society.

Article chronicle : Received : 06.03.2021; Revised : 26.04.2021; Accepted : 10.05.2021

Email : priyanka_fn@yahoo.co.in

Address of the Co-authors:

Arti Sankhala, Department of Food Science and Nutrition, College of Community and Applied Sciences, Maharana Pratap University of Agriculture and Technology, Udaipur (Rajasthan) India 